\title{
PEKERJA SENI YANG TERDAMPAK PANDEMI COVID-19 PADA SEKTOR INDUSTRI KREATIF DI INDONESIA
}

\author{
Robby Hidajat, Sri Wulandari, Yuyun Nur Astut, dan Muhammad Afaf Hasyimy \\ Universitas Negeri Malang \\ E-mail: robbyhidayad@um.ac.id
}

\begin{abstract}
Abstrak
Penelitian ini bertujuan mengetahui dampak pandemic Covid-19 terhadap para pekerja seni pada sektor industri kreatif di Indoesia. Pendekatan penelitian ini menggunakan kuantitatif. Populasi direncanakan menyasar 50 pekerja seni di tiga provinsi: Jawa Timur, Daerah Istimewa Yogyakarta dan Sumatera Selatan. Sampel teranalisis 21 responden dari Jawa Timur, 7 responden dari Daerah Istimewa Yogyakarta, dan 10 responden dari Sumatera Selatan. Analisis data menggunakan prosentase. Hasil penelitian ini menunjukkan para pekerja seni pada sektor industri kreatif yang terdampak pandemi Covid-19 mengalami dua dampak, yaitu: (1) Dampak yang berhubungan dengan nasib pekerjaannya, yaitu: (a) 13.1\% tidak mendapatkan hasil, (b) $26.3 \%$ putus asa dan pasrah, (c) $36.8 \%$ tidak mampu memprediksikan kondisi normal, dan (4) $52.6 \%$ menunggu bantuan pemerintah. (2) Dampak yang berhubungan dengan nasib penghasilannya, yaitu: (a) Pekerja seni tidak memiliki pengalaman menghadapi musibah sosial, (b) Ketika omset naik, tidak sadar bisa berinvestasi, tetapi sebaliknya ketika omset menurun, mereka tidak memiliki alternatif mencari penghasilan lain, sehingga menciptakan kelompok miskin baru.
\end{abstract}

Kata kunci: industri kreatif, usahawan seni, kreativitas, Covid 19

\section{ART WORKERS AFFECTED BY THE COVID-19 PANDEMIC IN THE CREATIVE INDUSTRY SECTOR IN INDONESIA}

\begin{abstract}
This study aims to determine the impact of the Covid-19 pandemic on art workers in the creative industry sector in Indonesia. This research approach is quantitative. The population is planned to target 50 art workers in three provinces: East Java, the Special Region of Yogyakarta, and South Sumatra. The sample analyzed was 21 respondents from East Java, 7 respondents from the Special Region of Yogyakarta, and 10 respondents from South Sumatra. Data analysis was in percentages. The results of this study show that art workers in the creative industry sector affected by the Covid-19 pandemic experienced two impacts, namely: (1) Impacts related to the fate of their work, namely: (a) 13.1\% did not get income, (b) $26.3 \%$ hopeless and resigned, (c) $36.8 \%$ unable to predict normal conditions, and (4) $52.6 \%$ waiting for government assistance. (2) Impacts related to the fate of their income, namely: (a) Art workers do not have experience dealing with social disasters, (b) When turnover increases, they are not aware that they can invest, but on the contrary, when turnover decreases, they have no alternative to find other income, thus creating a new poor group.
\end{abstract}

Keywords: creative industry, art entrepreneur, creativity, Covid 19 


\section{PENDAHULUAN}

Wabah pendemi Covid-19 yang melanda Indonesia mulai terasa pada awal bulan Maret 2020. Kondisi penyebaran yang menginfeksi manusia per 25 Maret 2020 tercatat lebih dari 700 orang positif (Anon n.d.). Virus yang terdeteksi antara 1-15 Januari 2020 di Wuhan China (Liu et al. 2020) telah mengguncang berbagai sendi kehidupan sosial masyarakat di seluruh dunia.

Langkah progresif pemerintah Republik Indonesia dalam pencegahan wabah Covid 19 telah dikeluarkan 11 peraturan Menteri Kesehataan untuk mengantipasi persebaran (Telaumbanua 2020). Implementasi peraturan tersebut salah satunya menginstruksikan belajar dan mengajar dari rumah, dan membatasi atau meniadakan kegiatan berkumpul, termasuk penyelenggaan ritual massal, dan setiap individu diedukasi agar menjaga jarak aman, dan mencuci tangan dengan air mengalir atau cairan disinfektan (Cahyono, Harahap, and Sukrajap 2019). Dengan tujuan dapat menghambat penularan virus yang diakibatkan melalui kontak langsung antar individu. Di kemudian hari tentu akan disusul berbagai aturan yang memaksa masyarakat untuk mematuhi pembatasan sosial, mulai dari tingkat pusat hingga ke berbagai daerah yang dipandang perlu mendapatkan kewaspadaan khusus.

Kebijakan pemerintah Republik Indonesia untuk mengatasi persebaran Covid-19 mulai terasa mengganggu stabilitas usaha dan kreativitas para pekerja seni di lingkungan industri kreatif. Pemerintah Republik Indonesia mengeluarkan kebijakan social distancing atau physical distancing sebagai strategi (Vrugt, Bickmann, and Wittkowski 2020). Berkaitan dengan kondisi kesiagaan terhadap menyebaran wabah Covid-19 dari hari ke hari berdampak social-ekonomi pada masyarakat dari berbagai lapisan (Zaharah and Kirilova 2020). Sudah barang tentu kondisi ini mempengaruhi kinerja para pekerja seni di lingkungan industri kreatif. Pekerja seni di lingkungan industri kreatif yang dimaksud adalah masyarakat yang bergerak di bidang kerajinan, seni, desain, hingga pemanfaat tenologi sosial media. Pekerja seni di lingkungan industri kreatif sangat bergantung dari sektor pariwisata. Dengan diberlakukan pengawasan mobilitas manusia, terutama kedatagan orang asing sudah dapat dipastikan sektor pariwisata menjadi lumpuh.

Kondisi pencegahan penyebaran Covid-19 yang memaksa setiap orang tidak keluar rumah atau berhubungan sosial dapat dipastikan akan berdampak pada para pekerja seni. Omset produksi dan jasa mengalami penurunan, hambatan, dan kehilangan pelanggan secara mendadak. Bahkan waktu 14 hari pertama di Bulan Maret 2020 masih belum menunjukan pencegahan Covid-19 (Yunus and Rezki 2020). Pemerintah tentu akan memberlakukan perpanjangan dan peningkatan kesiagaan. Hal ini benar-benar memberikan tekanan berat bagi pemerintah, karena pendapatan dan devisa dari berbagai sektor akan terhenti. Padahal beban kompensasi untuk memikirkan kehidupan rakyat semakin memberatkan (ARUM n.d.).

Tujuan penelitian ini diharapkan dapat memperoleh informasi yang lebih konkret, tentang kondisi para pekerja seni yang bergerak di lingkungan industri kreatif. Hal ini disebabkan sejak tahun 1998, sektor ini diharapkan dapat memberikan kompensasi pendapatan sektor non-migas (Poerwanto and Shambodo 2020). Demikian pula masyarakat dapat mengakses data kondisi pekerja seni yang bergerak di sektor industri kreatif. Kondisi para pekerja seni yang tersebar di seluruh Indonesia tentunya tidak bertahan diri dalam kondisi yang semakin tidak menentu, .Hal ini menjadi dampak pandemi Covid-19 terhadap para pekerja seni pada sektor industri kreatif di Indoesia.

\section{METODE}

Metode penelitian ini menggunakan diskriptif kuantitatif. Data teknik penjaringan data dengan menyebarkan angket pada masing-masing lokasi sebanyak 50 buah. Penyebaran angket dilakukan secara acak pada pekerja industri kreatif di tiga provinsi, yaitu Jawa Timur, Daerah Istimewa Yogyakarta dan Sumatera Selatan. Penyebaran angket melalui 
googel form mulai tanggal 3 sampai 13 April 2020. Responden yang menanggapi sebanyak 21 responden dari Jawa Timur, 7 responden dari Daerah Istimewa Yogyakarta, dan 10 responden dari Sumatera Selatan. Penelitian ini tidak dimaksudkan untuk membandingkan kondisi satu dengan kondisi yang lainnya. Analisis data menggunakan statistik sederhanam berupa diskriftif prosentase. Analisis data berupa penafsiran dari kecendrungan yang terdiskpsikan sesuai dengan permasalahan penelitian.

\section{Ruang Lingkup Polulasi}

Proses penelitian ini dilakukan dengan menggunakan sampelyang bersifatprobabilitas, yang artinya memberikan peluang sama bagi setiap unsur populasi untuk dipilih menjadi sampel. Sumber data pada artikel ini dari berbagai pelaku industri kreatif yang tersebar di tiga provinsi di Indonesia, yaitu Jawa Timur, Daerah Istimewa Yogyakarta, dan Sumatera Selatan. Alasan riial observasi ini dimaksudkan melihat karakteristik daerah dan pekerja seni di sektor industri kreatif. Jawa Timur memiliki pertumbuhan pekerja seni yang sangat pesat, utamanya di Malang dan di daerah Pantura, di Yogyakarta memiliki dominan kreator dan pekerja seni yang melimpah, sementara di Sumantra Selatan merupakan daerah yang dalam kondisi pertumbuhan industri kreatifnya.

\section{Instrumen Penelitian}

Pertama, peneliti menyiapkan instrumen berjumlah 14 kuesioner yakni: (1) Nama usahawan, (2) Usia, (3) Nomer handphone, (4) Alamat (5) Nama usaha atau industri (6) Bidang usaha (7) Bahan baku yang digunakan (8) Status dalam usaha (9) Lama waktu berusaha (10) strategi permodalan (11) Imbas wabah Covid-19 terhadap usaha, (12) Omset setelah adanya Covid 19 (13) Apa yang dilakukan jika omset menurun, dan (14) Berapa lama akan bertahan pada kondisi seperti saat ini, Kedua, peneliti menyebarkan 50 angket pada masingmasing daerah melalui media sosial (WhatsApp, Instagram, Facebook) dengan melalui link pada
Google Form. Ketiga, peneliti menganalisis hasil dengan metode kuantitatif sederhana untuk mendapatkan hasil dari penelitian, dan keempat menganalisis hasil prosentas kuantitatif tersebut dengan menginterpretasi jawaban dengan deskriptif kuantitatif.

\section{HASIL DAN PEMBAHASAN}

Respon yang diberikan oleh 38 responden pekerja industri kreatif di tiga provinsi di Indonesia secara acak dan telah dilakukan pengecekan, dan tabulasi data berdasarkan deskripsi secara persentase. Tabulasi data yang dipersentasekan adan 11 poin. Sementara data identitas, usia, alamat, dan nama bidang usaha tidak ditampilkan, karena peneliti berusaha untuk mengemukakan kondisi kecenderungan secara umum sebagai dampak pandemi Covid19 yang dialami para pekerja seni pada sektor industri kreatif di Indonesia.

Tabulasi data analisis untuk setiap poin pertanyaan dapat diperhatikan sebagai berikut:

Tabel 1. Golongan Industri Kreatif

\begin{tabular}{llcc}
\hline No & \multicolumn{1}{c}{$\begin{array}{c}\text { Bidang Industri } \\
\text { Kreatif }\end{array}$} & \multicolumn{2}{c}{ Responden } \\
& \multicolumn{2}{c}{ (Jumlah dan \%) } \\
\hline 1 & Kerajinan & 17 & $44,7 \%$ \\
2 & Desain & 6 & $15,7 \%$ \\
3 & Konveksi & 6 & $15,7 \%$ \\
4 & Fotografi & 3 & $7,8 \%$ \\
5 & Souvenir & 3 & $7,8 \%$ \\
6 & Periklanan & 2 & $5,2 \%$ \\
7 & Seni pertunjukan & 1 & $2,6 \%$ \\
\hline \multicolumn{2}{r}{ Total } & 38 & $100 \%$ \\
\hline
\end{tabular}

Tabel 1. Golongan industri kreatif tersebut menunjukkan bahwa responden yang memiliki usaha di bidang kerajinan sebanyak 17 orang pelaku usaha pada bidang kerajinan dengan jumlah prosentase $44,7 \%$, usaha pada bidang desain dan konveksi berjumlah 6 orang pelaku usaha dengan prosentase $15,7 \%$, usaha pada bidang fotografi dan souvenir masing-masing sebanyak 3 orang pelaku usaha dengan prosentase $7,8 \%$, usaha periklanan sebanyak 2 orang pelaku usaha dengan prosentase $5,2 \%$ dan yang paling sedikit berjumlah satu orang adalah yang bergerak di bidang seni 
pertunjukan dengan 1 orang pelaku usaha yang memiliki prosentase $2,6 \%$. Hasil penjaringan data, 7 bidang yang ditekuni responden masuk dalam wilayah industri kreatif yang dicantumkan dalam Badan Ekonomi Kreatif Republik Indonesia ((BeKraf 2018)).

Tabel 2. Bahan baku yang dipakai

\begin{tabular}{cccc}
\hline \multirow{2}{*}{ No } & Asal Bahan Baku & \multicolumn{2}{c}{$\begin{array}{c}\text { Responden } \\
\text { (Jumlah dan \%) }\end{array}$} \\
\hline 1 & Bahan baku lokal & 36 & $94,7 \%$ \\
2 & Bahan baku impor & 2 & $5,2 \%$ \\
\hline \multicolumn{2}{c}{ Total } & 38 & $100 \%$ \\
\hline
\end{tabular}

Tabel 2. bahan baku yang dipakai tersebut menunjukkan mayoritas 36 orang atau $94.7 \%$ responden menjawab memakai bahan baku lokal. 2 orang atau $5.2 \%$ responden yang memakai bahan impor. Hal ini dapat disimpulkan, para pelaku usaha membuat produk mereka dengan memanfaatkan bahan baku lokal yang secara otomatis mempunyai hubungan simbiosis mutualisme antara pelaku industri dan penyedia bahan baku. Sementara yang menggunakan bahan baku impor, tentu akan mengalami hambatan saat pandemi Covid 19. Data ini tentunya memberikan gambaran, bahwa potensi pekerja seni di Indonesia pada umumnya menggunakan bahan baku lokal.

Tabel 3. Status dalam usaha pekerja seni

\begin{tabular}{clcc}
\hline \multirow{2}{*}{ No } & \multirow{2}{*}{ Status } & \multicolumn{2}{c}{$\begin{array}{c}\text { Responden } \\
\text { (Jumlah dan \%) }\end{array}$} \\
\hline 1 & Pemilik & 36 & $94,7 \%$ \\
2 & Kreatif desainer & 2 & $5,2 \%$ \\
\hline & Total & 38 & $100 \%$ \\
\hline
\end{tabular}

Pada tabel 3, status kepemilikan tersebut menunjukkan mayoritas 36 orang responden dengan prosentase sebanyak $94.7 \%$ menjawab adalah pemilik dalam industri kreatif, dan hanya 2 orang responden dengan prosentase $5.2 \%$ yang menjadi kreatif desainer. Hal ini tentu memberikan gambaran positif dari program Pemerintah melalui Badan Ekonomi Kreatif Nasional, bahwa menumbuhkan gairah wirausahawan mandiri dengan terus memompa kreatifitas para pelaku industri kreatif (Mardiana, Tri. Wasiki, A. Heriningsih n.d.)
Tabel 4. Lama usaha berdiri

\begin{tabular}{cccc}
\hline No & Tahun & \multicolumn{2}{c}{$\begin{array}{c}\text { Responden } \\
\text { (Jumlah dan \%) }\end{array}$} \\
\hline 1 & $1-5$ tahun & 14 & $36,8 \%$ \\
2 & $6-10$ tahun & 12 & $31,5 \%$ \\
3 & $>10$ tahun & 12 & $31,5 \%$ \\
\hline & Total & 38 & $100 \%$ \\
\hline
\end{tabular}

Pada tabel 4, data yang hampir imbang pada lama berdirinya usaha. Pada rentang usaha 1-5 tahun yang memiliki responden terbanyak. Dengan rincian 14 reponden memiliki usaha dengan lama 1-5 tahun jika diprosentasekan sebanyak 36.8\%, sedangkan 12 responden dengan prosentase $31.5 \%$ telah merintis usaha selama 6-10 tahun, dan sisanya 12 responden dengan prosentase $31.5 \%$ memiliki usaha selama lebih dari 10 tahun. Tabel tersebut menunjukan bahwa ada faktor pertembuhan yang signifikan dengan program Pemerintah untuk menggairahkan para wirausahawan mandiri.

Tabel 5. Strategi yang digunakan saat omset meningkat

\begin{tabular}{|c|c|c|c|}
\hline \multirow{2}{*}{$\begin{array}{c}\text { No } \\
1\end{array}$} & \multirow{2}{*}{$\begin{array}{c}\text { Strategi } \\
\text { Menambah modal }\end{array}$} & \multicolumn{2}{|c|}{$\begin{array}{c}\text { Responden } \\
\text { (Jumlah dan \%) }\end{array}$} \\
\hline & & 8 & $21,0 \%$ \\
\hline 2 & $\begin{array}{l}\text { Menambah alat/mesin } \\
\text { baru }\end{array}$ & 8 & $21,0 \%$ \\
\hline 3 & Menambung & 8 & $21,0 \%$ \\
\hline 4 & Membuka usaha baru & 8 & $21,0 \%$ \\
\hline 5 & Rekrut karyawan lagi & 4 & $10,5 \%$ \\
\hline 6 & Investasi & 2 & $5,2 \%$ \\
\hline & Total & 38 & $100 \%$ \\
\hline
\end{tabular}

Tabel 5. di atas menggambarkan empat strategi yang berjumlah imbang yaitu 21,0\% dengan masing-masing jumlah responden sebanyak 8 pemilik usaha pada strategi memilih untuk menambah modal menambah alat/mesin baru, menabung, dan membuka usaha baru. Dan sisanya memilih merekrut karyawan sebanyak $10,5 \%$ dengan jumlah 4 orang pelaku usaha. Sebanyak 5,2\% memilih berinvestasi atau berjumlah 2 orang responden. Tabel 5 tentunya menunjukan prospek yang menggairahkan dari para pekerja seni di lingkungan industri kreatif. 
Tabel 6. Laju usaha terdampak imbas dari Covid 19

\begin{tabular}{clcc}
\hline No & & Terdampak & \multicolumn{2}{c}{$\begin{array}{c}\text { Responden } \\
\text { (Jumlah dan \%) }\end{array}$} \\
\hline 1 & Ya & 30 & $78,9 \%$ \\
2 & Tidak & 8 & $21,0 \%$ \\
\hline \multicolumn{2}{c}{ Total } & 38 & $100 \%$ \\
\hline
\end{tabular}

Tabel 6. Jumlah industri kreatif yang terkena dampak Covid 19 paling banyak, yaitu $78,9 \%$ atau sekitar 30 orang responden. Dan 8 orang responden sisanya dengan prosentase $21.0 \%$ mengaku usaha industri kreatifnya tidak terdampak efek Covid 19. Secara umum tampak kondisi memasuki bulan maret 2020. Para pengusaha merasakan ritme usaha yang semakin menurun.

Tabel 7. Omset usaha normal sebelum adanya Covid 19

\begin{tabular}{|c|c|c|c|}
\hline \multirow{2}{*}{$\begin{array}{c}\text { No } \\
1\end{array}$} & \multirow{2}{*}{$\begin{array}{l}\text { Omset dalam Hitungan } \\
\text { Juta Rupiah Per Bulan }\end{array}$} & \multicolumn{2}{|c|}{$\begin{array}{c}\text { Responden } \\
\text { (Jumlah dan \%) }\end{array}$} \\
\hline & & 0 & $0 \%$ \\
\hline 2 & $<1$ juta rupiah & 5 & $13,1 \%$ \\
\hline 3 & 1-10 juta rupiah & 23 & $60,5 \%$ \\
\hline 4 & 10-50 juta rupiah & 8 & $21,0 \%$ \\
\hline 5 & $>50$ juta rupiah & 2 & $5,2 \%$ \\
\hline & Total & 38 & $100 \%$ \\
\hline
\end{tabular}

Tabel 7. Omset per bulan yang paling tinggi sebanyak $60,5 \%$ atau sekitar 23 orang responden menunjukkan bahwa usaha industri kreatifnya menghasilkan omset dalam sebulan sebesar 1-10 juta rupiah, angka tertinggi kedua dengan $21.0 \%$ atau 8 orang responden menghasilkan omset 10-50 juta rupiah, angka tertinggi ketiga dengan 5 orang responden dengan prosentase sebanyak $13.1 \%$ memiliki omset kurang dari 1 juta rupiah dan yang paling sedikit responden sebanyak $5,2 \%$ atau 2 responden mengatakan pendapatannya dalam sebulan bisa mencapai lebih dari angka 50 juta rupiah.
Tabel 8. Omset usaha setelah adanya Covid 19

\begin{tabular}{clcc}
\hline No & $\begin{array}{c}\text { Omset dalam Hitungan } \\
\text { Juta Rupiah Per Bulan }\end{array}$ & \multicolumn{2}{c}{$\begin{array}{c}\text { Responden } \\
\text { (Jumlah dan \%) }\end{array}$} \\
\hline 1 & Tidak ada pemasukan & 5 & $13,1 \%$ \\
2 & $<1$ juta rupiah & 8 & $21,0 \%$ \\
3 & $1-10$ juta rupiah & 23 & $60,5 \%$ \\
4 & $10-50$ juta rupiah & 2 & $5,2 \%$ \\
5 & $>50$ juta rupiah & 0 & $0 \%$ \\
\hline & Total & 38 & $100 \%$ \\
\hline
\end{tabular}

Tabel 8. Omset setelah merebaknya Covid 19 sangat menurun drastis jika dibanding dengan omset normal sebelum adanya wabah Covid 19. Penurunan tajam omset menjadi angka kurang dari 1 juta adalah sebanyak 8 responden atau 21,0\%. Pada omset 1-10 juta prosentasi $60,5 \%$ atau 23 orang responden. Dan 2 orang responden atau 5,2\% berpenghasilan kurang dari 10-50 juta rupiah. Fakta lain yang mencengangkan adalah adanya responden yang tidak mendapat keuntungan sama sekali akibat dampak Covid 19 yang merebak, penghasilan mereka 0 rupiah dengan jumlah responden sebanyak 5 responden atau 13,1\%.

Tabel 9. Strategi yang dilakukan sebelum pendemi Covid 19

\begin{tabular}{clcc}
\hline No & \multicolumn{1}{c}{ Strategi } & \multicolumn{2}{c}{$\begin{array}{c}\text { Responden } \\
\text { (Jumlah dan \%) }\end{array}$} \\
\hline 1 & $\begin{array}{l}\text { Model tabungan } \\
\text { pribadi }\end{array}$ & 10 & $26,3 \%$ \\
2 & $\begin{array}{l}\text { Mencari pinjaman } \\
\text { modal Bank }\end{array}$ & 5 & $13,1 \%$ \\
3 & $\begin{array}{l}\text { Peromosi melalui iklan } \\
4\end{array}$ & 5 & $13,1 \%$ \\
& $\begin{array}{l}\text { Kolaborasi sesama } \\
\text { pengusaha }\end{array}$ & 4 & $10,5 \%$ \\
5 & $\begin{array}{l}\text { Mengembangkan } \\
\text { produk }\end{array}$ & 4 & $10,5 \%$ \\
6 & $\begin{array}{l}\text { Merekrut karyawan } \\
\text { profesional }\end{array}$ & 3 & $7,8 \%$ \\
7 & Mengikuti festival & 7 & $18,4 \%$ \\
\hline & $\quad$ Total & 38 & $100 \%$ \\
\hline
\end{tabular}

Tabel 9. Strategi sebelum terjadinya pendemi Covid 19. Tergambar pada tabel tabel 9. Pekerja seni yang menginvestasikan modal pribadi 10 responden atau $26,3 \%$, mencari pinjaman modal ke Bank 5 responden atau 13,1\%, melakukan promosi melalui 
iklan 5 responden atau 13,1\%, kolaborasi sesama pengusaha 4 responden atau $10,5 \%$, mengembangkan diversivikasi produk 4 responden atau 10,5\%, merekrut karyawan profesional 3 responden atau $7,8 \%$, dan mengikuti festival 7 responden atau $18,4 \%$.

Tabel 10. Strategi yang digunakan ketika terjadi pendemik covid 19

\begin{tabular}{clcc}
\hline No & \multicolumn{1}{c}{ Strategi } & \multicolumn{2}{c}{$\begin{array}{c}\text { Responden } \\
\text { (Jumlah dan \%) }\end{array}$} \\
\hline 1 & Menurunkan produksi & 5 & $13,1 \%$ \\
2 & Cari strategi baru & 5 & $13,1 \%$ \\
3 & Pasang iklan di sosial & 5 & $13,1 \%$ \\
& media & & \\
4 & Mengurangi karyawan & 3 & $7,8 \%$ \\
5 & Cari pinjaman modal & 5 & $13,1 \%$ \\
6 & Cari peluang usaha & 5 & $13,1 \%$ \\
& lain & & \\
7 & Sabar dan berdoa & 10 & $26,3 \%$ \\
\hline \multicolumn{2}{c}{ Total } & 38 & $100 \%$ \\
\hline
\end{tabular}

Tabel 10. Menggambarkan strategi saat Covid 19 mewabah dan mempengaruhi kinerja industri kreatif, sehingga harus melakukan tindakan strategis, yaitu 10 orang responden atau 26,3\% hanya bisa sabar dan berdoa menunggu wabah Covid 19 selesai sembari terus berkarya tanpa entah kapan kondisi pandemik ini akan kembali normal. Jawaban lainnya imbang antara menurunkan produksi, cari strategi baru, pasang iklan di sosial media, cari pinjaman modal dan cari peluang usaha lain dengan masing-masing 5 responden atau $13.1 \%$. Begitu pula dengan upaya mengurangi karyawan ada 3 orang responden yang menjawab dengan prosentase $7.8 \%$.

Tabel 11. Perkiraan bertahan pada kondisi saat ini

\begin{tabular}{clcc}
\hline No & \multicolumn{1}{c}{ Jawaban } & \multicolumn{2}{c}{$\begin{array}{c}\text { Responden } \\
\text { (Jumlah dan \%) }\end{array}$} \\
\hline \multirow{2}{*}{1} & $\begin{array}{l}\text { Tidak bisa mem- } \\
\text { prediksi sampai kapan }\end{array}$ & 14 & $36,8 \%$ \\
2 & $1-3$ bulan & 5 & $13,1 \%$ \\
3 & $>5$ bulan & 5 & $13,1 \%$ \\
4 & $\begin{array}{l}\text { Menunggu sampai } \\
\text { kondisi normal lagi }\end{array}$ & 14 & $36,8 \%$ \\
\hline & \multicolumn{1}{l}{ Total } & 38 & $100 \%$ \\
\hline
\end{tabular}

Tabel 11. Perkiraan bertahan pada kondisi dengan wabah Covid 19 yang marak responden sebanyak 14 orang responden atau $36,8 \%$ menjawab tidak dapat memprediksi dan hanya bisa menunggu sampai kondisi normal kembali. Terbanyak kedua menjawab 1-3 bulan ke depan dapat bertahan dan lebih dari 5 bulan bisa optimis bertahan sebanyak 5 orang responden atau $13,1 \%$.

Tabel 12. Usaha untuk bertahan dalam kondisi krisis

\begin{tabular}{clcc}
\hline No & \multicolumn{1}{c}{ Jawaban } & \multicolumn{2}{c}{$\begin{array}{c}\text { Responden } \\
\text { (Jumlah dan \%) }\end{array}$} \\
\hline 1 & $\begin{array}{l}\text { Menunggu bantuan } \\
\text { pemerintah }\end{array}$ & 20 & $52,6 \%$ \\
2 & $\begin{array}{l}\text { Keringanan jasa } \\
\text { perbankan }\end{array}$ & 4 & $10,5 \%$ \\
3 & $\begin{array}{l}\text { Menggunakan } \\
\text { tabungan pribadi }\end{array}$ & 4 & $10,5 \%$ \\
4 & Menutup usaha & 10 & 26,3 \\
\hline & Total & 38 & $100 \%$ \\
\hline
\end{tabular}

Tabel 12. Usaha dalam masa kondisi kritis selama wabah Covid 19. Responden yang menunggu bantuan pemerintah sebanyak 20 atau $52,6 \%$, responden yang mengharap keringanan jasa perbankan 4 orang atau 10,5\%. Responden yang menggunakan tabungan pribadi untuk bertahan sebanyak 4 orang atau $10,5 \%$, dan yang bertekat menutup usaha sementara sebanyak 10 orang atau $26 \%$.

Pekerja seni di lingkungan industri kreatif merasakan omset yang nenurun secara tajam, hingga ada yang tanpa penghasilan dan hanya berpendapatan kurang dari satu juta rupiah saja (tabel 7). Hal ini dapat dibandingkan dengan kondisi omset normal para pekerja seni (tabel 8). Maka dapat dimaknai, bahwa para pekerja seni di lingkungan industri kreatif mengalami tekanan ekonomi yang cukup berat selama adanya pandemi Covid 19 ini. Jika diperhatikan omset normal dapat mencapai satu juta rupiah hingga yang paling tinggi Rp. 10.000.000,dan dibandingkan mereka yang pada kondisi merebaknya Covid 19 ini menjadi tidak mendapatkan penghasilan sama sekali bagi mereka yang menjadi pekerja, bukan pemilik 
modal. Tentu saja gambaran para pekerja seni di lingkungan industri kreatif memang mengalami tekanan ekonomi. Perhatikan analisis kurva omset normal dan penurunan penghasilan dalam kurun waktu 14 hari social distancing.

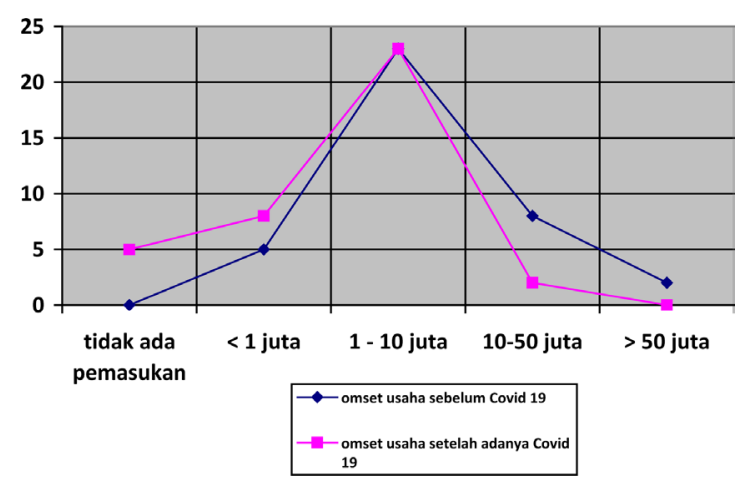

Kurva 1. Omset normal dan penurunan penghasilan dalam kurun waktu 14 hari social distancing
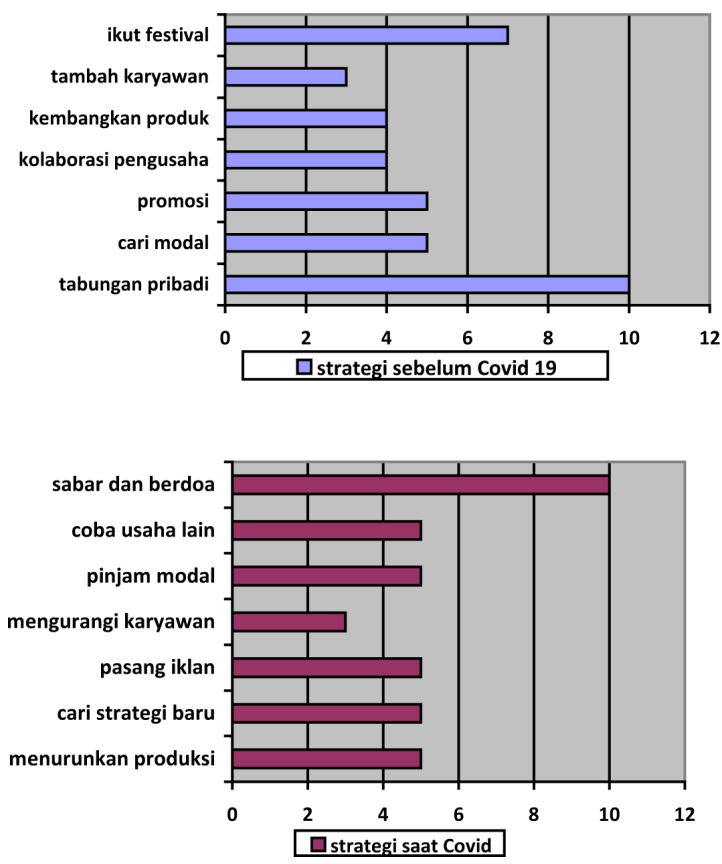

Kurva 2 dan 3. Perbandingan antara strategi sebelumdan saat Covid 19

Hasil analisis di atas tentunya berdampak pada lamanya kondisi wabah pendemi Covid 19 ini berlangsung. Para pekerja seni mencoba memprediksikan (1) tidak ada yang dapat memprediksikan atau hanya bersikap menunggu kondisi menjadi pulih kembali (tabel 10), artinya, pekerja seni tidak memiliki pengalaman menghadapi kondisi bencana sosial seperti sekarang ini. Akibatnya jika ada kelipatan waktu 14 ke depan, maka kondisi perekonomian para pekerja seni akan mengalami pengurangan modal, karena modal akan digunakan untuk kebutuhan konsumtif. Sehingga mereka harus melepaskan para pekerjanya. Karena mereka yang sadar untuk menanamkan modal hanya 2 responden atau $5,2 \%$.

Sehingga terjadi perbandingan antara kebutuhan pengeluaran konsumtif dan modal yang dimiliki menjadi berkurang secara gradual. Sehingga terjadi sikap apatis, keputusan mereka adalah pasrah, menyerahkan pada kuasa Tuhan (tabel 9).

Perkiraan bertahan pada kondisi wabah Covid 19 ini, pekerja seni tidak bisa menentukan perkiraan usahanya kembali normal dan mengembangkan usahanya kembali. Hal ini dikarenakan prediksi yang di luar rencana. Di musim bulan menjelang puasa mereka memprediksi pesanan akan membludak seperti biasanya, sehingga dana yang didapatkan sudah terlanjur dibelikan bahan baku sebanyak mungkin untuk persiapan pemesanan yang diprediksi dalam jumlah besar, akan tetapi adanya Covid 19 ini pekerja seni terancam tidak dapat melanjutkan usahanya. Demi mempertahankan kelangsungan hidup, kemungkinan yang dapat dipilih adalah dengan beralih atau banting setir mencoba usaha baru yang memang sangat banyak permintaan dari konsumen saat kondisi pandemi Covid 19 seperti kebutuhan masker, hand sanitizer, dan cairan disinfektan.

\section{KESIMPULAN}

Kondisi pekerja seni di lingkungan industri kreatif di Indonesia ketika terjadi pendemi Covid 19, dan keputusan pemerintah untuk social distensing dan diikuti oleh keputusankeputusan untuk membatasi pergerakan sosial. Bahkan hingga diberlakukan Pembatasan Sosial Berskala Besar (PSBB), dan juga pelarangan atau pengawasan mobilitas sosial 
untuk mudik(Pulang kampung). Hasil penelitian menunjukkan, pekerja seni tidak memiliki pengalaman dalam menghadapi musibah sosial, sehingga pada saat omset mereka naik tidak sadar untuk berinvestasi finansial. Bahkan pada saat terjadi musibah sosial yang bersekala global ini tidak memiliki alternatif dan kemampuan mempredisikan. Sehingga yang hanya bisa mereka lakukan adalah mengurangi tenaga kerja, dan menggunakan modal sebagai kebutuhan konsumtif pribadi. Sehingga dalam waktu berjalan sepanjang masa pendemi Corona 19 menunjukan akan terjadinya kelompok miskin baru.

\section{DAFTAR PUSTAKA}

Anon. n.d. "(PDF) ESTIMATION OF COVID-19 REPRODUCTIVE NUMBER CASE OF INDONESIA (Estimasi Angka Reproduksi Novel Coronavirus (COVID19) Kasus Indonesia)."

ARUM, RISKA. n.d. "Pembatasan Sosial Di Indonesia Akibat Virus Corona Ditinjau Dari Sudut Pandang Politik."

BeKraf. 2018. KaTa Kreatif: Langkah Jejaring Kabupaten/Kota Kreatif Indonesia. 1st ed. edited by J. Soehardjo. Jakarta: Badan Ekkonomi Kreatif Republik Indonesia.

Cahyono, Muhammad Sigit, Dewi Handayani Harahap, and Muhammad Ali Sukrajap. 2019. "Penerapan Teknologi Produksi Makanan Olahan Untuk Pengembangan Usaha Kecil Dan Menengah Di Kota Bandung." KACANEGARA Jurnal Pengabdian Pada Masyarakat 3(1).

Gorbalenya, Alexander E. 2020. "Severe Acute Respiratory Syndrome-Related Coronavirus - The Species and Its Viruses, a Statement of the Coronavirus Study Group." BioRxiv 2020.02.07.937862.

Liu, Weiyong, Qi Zhang, Junbo Chen, Rong Xiang, Huijuan Song, Sainan Shu, Ling Chen, Lu Liang, Jiaxin Zhou, Lei You, Peng Wu, Bo Zhang, Yanjun Lu, Liming Xia, Lu Huang, Yang Yang, Fang Liu, Malcolm G. Semple, Benjamin J. Cowling, Ke Lan, Ziyong Sun, Hongjie Yu, and Yingle Liu. 2020. "Detection of Covid-19 in Children in Early January 2020 in Wuhan, China." New England Journal of Medicine.

Mardiana, Tri. Wasiki, A. Heriningsih, Sucahyo. n.d. "Menciptakan Peluang Usaha Ecoprint Berbasis Potensi Desa Dengan Metode RRA Dan PRA." Prosiding Konferensi Pendidikan Nasional "Strategi Dan Implementasi Pendidikan Karakter Pada Era Revolusi Industri 4.0."

Poerwanto, Poerwanto, and Yoedo Shambodo. 2020. "Revolusi Industri 4.0: Googelisasi Industri Pariwisata Dan Industri Kreatif." Journal of Tourism and Creativity 4(1):5972.

Rusdi, Farid. n.d. "PODCAST SEBAGAI I\{Bibliography\}NDUSTRI KREATIF." SNIT 2012 1(1):91-94.

Telaumbanua, Dalinama. 2020. "Urgensi Pembentukan Aturan Terkait Pencegahan Covid-19 Di Indonesia." QALAMUNA: Jurnal Pendidikan, Sosial, Dan Agama 12(01):59-70.

Vrugt, Michael te, Jens Bickmann, and Raphael Wittkowski. 2020. "Effects of Social Distancing and Isolation on Epidemic Spreading: A Dynamical Density Functional Theory Model."

Yunus, Nur Rohim, and Annissa Rezki. 2020. "Kebijakan Pemberlakuan Lock Down Sebagai Antisipasi Penyebaran Corona Virus Covid-19." SALAM: Jurnal Sosial Dan Budaya Syar-I 7(3):227-38.

Zaharah, Zaharah, and Galia Ildusovna Kirilova. 2020. "Impact of Corona Virus Outbreak Towards Teaching and Learning Activities in Indonesia." SALAM: Jurnal Sosial Dan Budaya Syar-I 7(3):269-82. 